
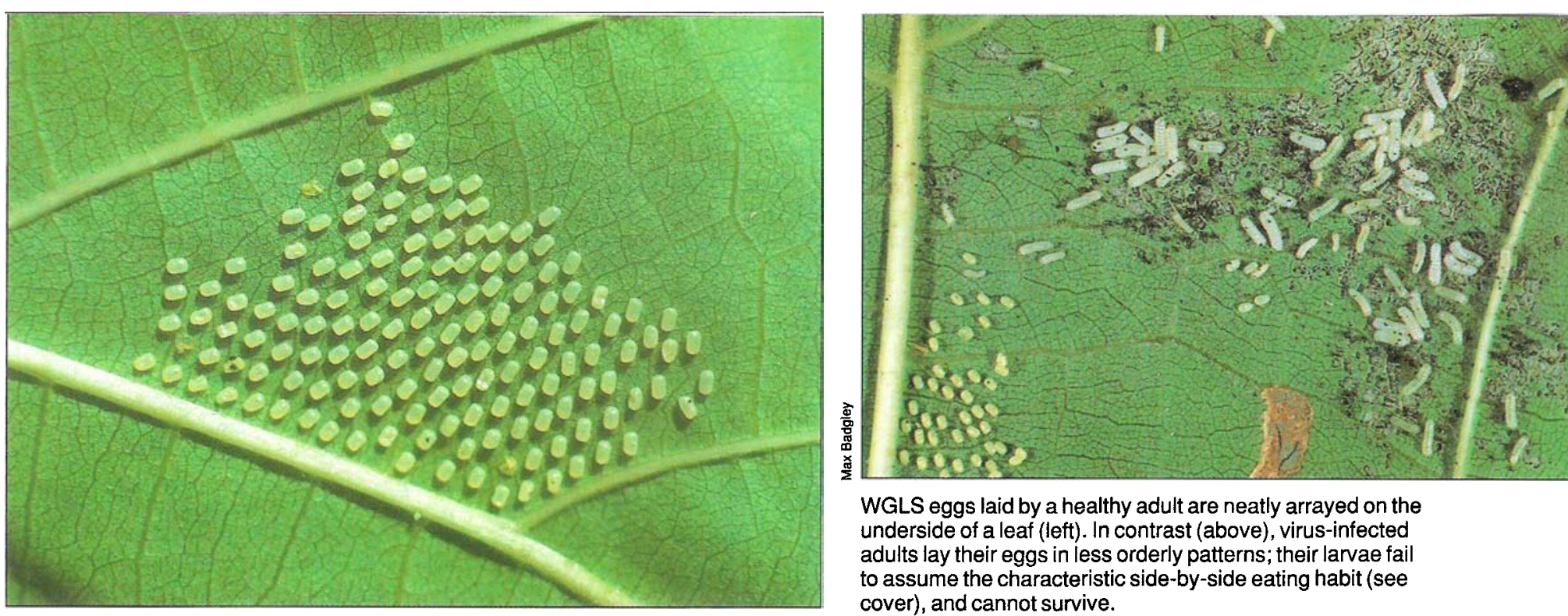

WGLS eggs laid by a healthy adult are neatly arrayed on the underside of a leaf (left). In contrast (above), virus-infected adults lay their eggs in less orderly patterns; their larvae fail to assume the characteristic side-by-side eating habit (see cover), and cannot survive.

\title{
Granulosis virus: biological control for western grapeleaf skeletonizer
}

\author{
Vernon M. Stern a Brian A. Federici
}

\section{Granulosis virus disease of west- ern grapeleaf skeletonizer acts much like a classical biological control agent. Infected males trans- mit the disease to healthy females during mating, and infected fe- males transmit it to their offspring. Egg production is reduced and lar- val mortality is very high.}

Larvae of the western grapeleaf skeletonizer (WGLS), Harrisina brillians Barnes \& McDunnough, are serious defoliating pests of vineyards and backyard grapevines. When vines are severely defoliated, the larvae feed on the fruit, causing bunch rot, which usually destroys the entire fruit cluster. In addition, urticating spines on the large larvae sting, causing skin welts on field workers who touch them. Insecticides are often applied just before harvest to protect field workers from the spines.

Originally distributed through Arizona, New Mexico, Nevada, Utah, Colorado, and Mexico's Sonora, Chihuahua, Coahuila, and Aguascalientes States, WGLS was first found in California in 1941 near San Diego. In a short time it had become a serious pest in commercial vineyards. In 1961, WGLS was found on backyard grapes near Fresno. By 1975, despite an intensive eradication program, infestations were firmly established in several areas of central and northern California.

In the early 1950s, a parasitic wasp (Apanteles harrisinae Muesebeck) and a parasitic fly (Amatadoria misella [Wulp]) collected in Sonora, Mexico, and in Árizona were established in San Diego County. During this early period, a disease was observed attacking WGLS larvae in the field. The disease was inadvertently introduced into San Diego County along with the beneficial parasites. First thought to be a bacterium, the cause of the disease was later identified as a granulosis virus (HbGV). Indeed, this virulent virus was continually wiping out the WGLSlarval stock used for production of the two insect parasites.

\section{Healthy WGLS eggs and larvae}

The capsule-shaped, pale-yellow eggs of WGLS are laid in a cluster on the underleaf. There may be as few as 20 to 25 or as many as 300 or more eggs in a cluster, with an average count of 96 . Essentially, all eggs hatch. The first of the five larval stages is pale white, and individuals are about $1 / 20$ inch long. Their feeding appears as a white spot on the upper leaf. The larvae habitually feed side-by-side on the leaf underside through the first three stages and into the early fourth stage.
Second-stage larvae are about $1 / 8$ to $1 / 16$ inch long, and third-stage larvae are about $1 / 4$ to $5 / 16$ inch long. The latter stage exhibits two large brown bands and five narrow bands. Fourth-stage larvae are about $7 / 16$ inch long, and fifth-stage larvae are about $5 / 8$ inch long. The seven circular bands on the body of a fifth-stage larva are blackish purple, and between the bands the body color is bright yellow. A fully grown larva spins a silken cocoon in the trash around the base of vines or under loose bark on the trunk and arms, and then pupates.

\section{Typical HbGV infection symptoms}

Unlike healthy WGLS females, those arising from infected larvae frequently scatter their eggs over the leaf. Often, two or three eggs will be stacked on top of one another. Some eggs fail to hatch and collapse into a small yellow mass.

In some egg batches, the infected, newly hatched larvae spin down below the leaf on a silken thread and die. This early symptom seems to indicate a high level of infection that results from transmission via the eggthat is, the virions are on the outer egg shell, which is consumed by the hatching larva.

The degree of infection can be determined superficially by noting the larval stages (first to early fourth) that abandon their side-by-side feeding habit. Disruption of this feeding habit is a clear predictor of early death. Moreover, diseased larvae feed in a spotty manner, consuming tiny patches of leaf tissue.

HbGV infects the midgut, so the larvae usually have diarrhea, leaving brownish discharges on the leaves. Diseased larvae gradually shrink in body length. Most fall to the ground, but a few remain attached to the leaves.

Pupal mortality varies, as does adult failure to escape from the cocoon. We observed a wide variation in wingspan and body size in moths that developed from infected larvae. This may result from poor nutrition, which in turn results from viral damage to the midgut. 


\section{Re-analysis of HbGV}

In 1952, Professor E. Steinhaus (UC Berkeley) placed two small vials of pulverized, dried HbGV worms in a freezer. In 1974, one vial was sent to UC Riverside and stored frozen. Then, in 1979, 27 years after Steinhaus had placed the material in a freezer, we took a matchhead-sized amount to the field and added $1 / 10$ ounce water. The solution was painted with a camel's-hair brush in front of five different groups of second-stage larvae, feeding side by side. Seven days later, nearly all larvae were dead. Untreated larvae had molted to the third stage. This showed that HbGV could be an important biological control agent against WGLS in the San Joaquin Valley. A project was initiated to increase the virus stock.

In 1981, we conducted preliminary mating studies and showed that moths arising from surviving larvae that had been fed $\mathrm{HbGV}$ to increase our virus stock carried the virus. They transmitted the disease to the next generation (table 1). We also found that HbGV overwinters in the hibernating pupa in the cocoon.

In 1982, we sprayed a low dosage of $\mathrm{HbGV}(1 / 3$ ounce of pulverized, dried, diseased larvae per acre) on small areas of native wild grape (Vitis californica) heavily infested with WGLS and growing on the banks of the Kaweah and Tule rivers in Tulare County. One to two acres of native grape vines were sprayed. The same areas were treated on the three generations of WGLS.

If we were correct in our preliminary mating studies of $\mathrm{HbGV}$-infected moths, the adults arising from thousands of larvae with low-level infections would disperse. $\mathrm{HbGV}$ would be carried into commercial

TABLE 1. Mating crosses of nonvirus-carrying male and female adults compared with mating crosses where one or both sexes were fed HbGV in the larval stage and effect on egg production and larval survival

\begin{tabular}{|c|c|c|c|c|c|c|}
\hline Year/type cross & $\begin{array}{l}\text { No. of } \\
\text { mating } \\
\text { pairs }\end{array}$ & $\begin{array}{c}\text { Females } \\
\text { laying } \\
\text { no eggs }\end{array}$ & $\begin{array}{l}\text { Mean no. } \\
\text { eggs laid } \\
\text { per female }\end{array}$ & $\begin{array}{l}\text { Percent } \\
\text { reduction }\end{array}$ & $\begin{array}{l}\text { No. larvae } \\
\text { reaching } \\
5 \text { th instar }\end{array}$ & $\begin{array}{c}\text { Percent } \\
\text { reduction }\end{array}$ \\
\hline \multicolumn{7}{|l|}{$\begin{array}{l}1981 \\
\text { Nonvirus female }\end{array}$} \\
\hline $\begin{array}{c}x \\
\text { Nonvirus male }\end{array}$ & 15 & 0 & 274 & - & 266 & - \\
\hline GV temale & & & & & & \\
\hline GV male & 15 & 2 & 73 & 73 & 0.6 & 100 \\
\hline \multicolumn{7}{|l|}{$\begin{array}{l}1983 \\
\text { GV female }\end{array}$} \\
\hline GV male & 37 & 9 & 79 & 71 & 36 & 86 \\
\hline GV female & & & & & & \\
\hline$\stackrel{x}{\text { Nonvirus male }}$ & 27 & 4 & 82 & 70 & 29 & 89 \\
\hline Nonvirus female & & & & & & \\
\hline GV male & 11 & 3 & 102 & 63 & 38 & 86 \\
\hline
\end{tabular}

that had been cleaned with a bleach solution.

The moths tend to emerge from the pupal stage in the morning. Mating occurs soon after the adults are able to fly. WGLS is a very gentle moth.

The tip of the fore-wing of each sex was clipped with medical scissors to identify the moths after uncoupling. Each mating pair was taken to the field and placed in a separate $2.5-\times 3.5$-foot organdy sleeve cage enclosing a Thompson Seedless' grape cane to provide an egg-laying site and food for the larvae. Each cane was examined to make sure it was free of WGLS eggs or larvae that might influence our results.

The field data showed the high dosage to larvae had no greater effect on the number of eggs laid and the number of larvae reaching the fifth stage than did the low dosage. Therefore, the 1983 data are presented only as the three types of mating crosses.

The sleeve cages were monitored daily until each female died. All leaves on the grape cane were then examined and all eggs recorded. The average healthy female mated to a healthy male (1981 tests) laid 274 eggs (table 1). Nearly all healthy females laid one or more egg batches containing more than 90 eggs. Essentially, all eggs laid by these females hatched, and the larvae completed development to the fifth stage.

The data showed HbGV to markedly reduce the number of eggs laid when both sexes or either sex carries the virus. Infected or nonvirus females who mated to diseased males laid an average of 84 eggs, about $70 \%$ less than the untreated female $\times$ male cross. Larval mortality from $\mathrm{HbGV}$-carrying moths was about $90 \%$, compared with the nonvirus female $\times$ male cross.

\section{Conclusions}

The transmission of $\mathrm{HbGV}$ from one WGLS generation to the next makes this virus an ideal candidate for classical biological control. In a long sequence of contaminated moth generations, the areawide WGLS population in the San Joaquin Valley will gradually decrease to moderate levels.

Spread of the virus by contaminated moths will be very slow because the moths do not fly well. Moreover, rules and regulations of the U.S. Environmental Protection Agency and the California Department of Food and Agriculture currently restrict $\mathrm{HbGV}$ spray treatment to no more than 10 acres per year.

Vernon M. Stern and Brian A. Federici are Professors, Department of Entomology, University of California, Riverside. This research was supported in part by funds from the California Raisin Advisory Board, California Table Grape Commission, Winegrowers of California, the UC/IPM Project, and the American Vineyard Foundation. 